\title{
PUBLIC PARTICIPATION IN LAND USE PLANNING AND THE BUILDING OF A CIVIL SOCIETY
}

\author{
Magdalena Załęczna, assoc. prof., PhD \\ University of Lodz \\ e-mail:mzaleczna@uni.lodz.pl
}

\begin{abstract}
Poland is going through the process of building social capital. The process requires citizens' involvement in local matters. The country has created institutional instruments to foster a sense of collective responsibility for local matters, such as public consultations and debates, access to public information, referenda, and participatory budgeting. The practical use of these instruments and the slow process of building a civil society, however, pose a problem.

Land use planning has a multifaceted character and is the arena for many local conflicts frequently fuelled by discrepancies between private and public interests. The participation of local communities provides an opportunity to work out socially acceptable solutions and helps identify likely sources of conflicts, as well as preventing the isolation of local authorities. It is also a necessary building block in creating a civil society.

The author's search for the causes of citizens' reluctance to actively participate in land use planning processes is set in the context of social capital and the laborious process of building a civil society. The conclusions of the study offer a critical perspective on the current solutions regulating the residents' involvement in land use planning. The study is based on a review of literature and the author's own research.
\end{abstract}

Key words: social participation, planning, conflict, civil society.

JEL Classification: A14, O21, R14.

Citation: Załęczna M., 2018, Public Participation in Land Use Planning and the Building of a Civil Society, Real Estate Management and Valuation, vol. 26, no. 2, pp. 23-32.

DOI: $10.2478 /$ remav-2018-0013

\section{Introduction}

"What we loftily call freedom does not come down to the ceremonious act of overthrowing of a tyrant, a change of a political systems, the proclamation of democracy and selecting governments through free elections, because it also, or perhaps above all, encompasses a less definable public space, in which citizens are always free to do whatever they wish and thus set, without even knowing and thinking about it, the limits and direction of their government's actions."

SZACKI 1997

The purpose of a local zoning process is to define the possible uses of different pieces of land properties by assigning them potential functions and infrastructure (both existing and projected). The process is required to weigh private interests against public interests and to take into account the possible clashes among private entities, as well as between private and public entities. Local residents should not only have the opportunity to present their opinions, but they should also trust that they will be respected by local law-makers. Unfortunately, everyday practice shows otherwise. Public participation is formal and superficial, discouraging those who might be interested, as their comments and proposals have no effect on reality (BUCZEK 2006; PAWŁOWSKI 2015). 


\section{S sciendo}

Many publications on national and local solutions in this area and on their consequences indicate that the above problems are not specific to the Polish land use planning system (PACIONE 2014; NARED et al. 2015; CALDEIRA, HOLSTON 2017; HANSSEN, FALLETH 2014).

What makes citizens' participation in land use planning difficult is that it attracts mainly individuals rather than organised groups (such as trade unions or employers' associations in the industrial setting). Local residents rarely organise themselves into groups and the opinions of individuals can be easily disparaged. Moreover, Polish law does not require the decision-making bodies to assess the real interest of a resident who will be immediately affected by some specific form of land use, but cannot cite a relevant protective provision (NIEWIADOMSKI 2006). The possibility of weighing legal interests is also significantly restricted, which influences the role of public participation. The Act of 3 October 2008 on the disclosure of information on the environment and its protection, public participation in environmental protection and environmental impact assessments (Dz. U. of 2016, item. 353) did not change this situation, notwithstanding its provisions allowing citizens to access project documentation.

A major problem regarding citizens' participation in land use planning activities in Poland is the willingness, or rather lack thereof, of the public to take part in participatory decisions regarding local matters and to collaborate with other local residents and local government bodies. It is also notable that local authorities frequently consider residents' participation in decision making to be yet another nuisance imposed by statutory laws. It is not without satisfaction that they point to the low numbers of participants and use them as an argument in support of their arbitrary decisions.

In seeking the causes behind the citizens' lack of participation in land planning processes, the author of this article refers to the concept of a civil society. An outline of social capital and of the laborious process of building a civil society is followed by a description of the basic regulations governing land use and planning, and by a review of findings of selected authors who study this process from the participatory perspective. This part sets the context for studying citizens' participation in planning activities in a selected town in the years 2003-2015 and a case study of a planning process that turned into a major local conflict and mobilised a group a local residents into action. The author takes special interest in the awareness and activity of residents that took part in this process. The conclusions of the study allow a critical perspective on the current solutions governing the contribution of local communities to land use planning processes. The article is based on a review of literature and the author's analysis of land use planning in the selected town.

\section{Civil society - a review of literature}

While the concept of "a civil society" dates back to ancient thought, it was not until modern times, i.e. the $18^{\text {th }}$ and $19^{\text {th }} \mathrm{C}$., that its interpretation became more elaborate as a result of philosophers' interest in social development (SOWA 2012). Even so, the distinctive characteristics of a civil society were not defined, nor was a wider discussion on this subject taken up. In the $20^{\text {th }} \mathrm{c}$., in keeping with their founding ideology, socialist countries made efforts to blend the words "citizen" and " comrade", but these were thwarted by socialist societies, particularly by the Polish society, which objected to this appropriation of the word "citizen" and equated a civil society with one that has its own organisation, a sense of dignity, and resists socialist authorities (SOWA 2012).

As a topic of philosophical and sociological debates and an object of interest for political sciences, a civil society is understood in many ways. Its multifaceted nature allows the application of many criteria and definitions, which, being diverse, are not necessarily contradictory. The three main definitional approaches to a civil society seek to: (1) determine its position between the State and the market, also arguing that its main goal is to support collective interests and enable collective action, (2) present it as a type of society in the normative sense, (3) determine its place in the space of public debate, showing it as an exercise in "active" citizenship and creating the public sphere (Edwards 2009). This article utilizes the definition of a civil society created by KALISIAK-MĘDELSKA, which presents it as a space for debates and discussions that aim to work out solutions for the common good, which has its distinctive structure, networks and relationships existing independently of the control system of the state (KALISIAK-MĘDELSKA 2015).

Social capital, frequently called a social adhesive, an agent integrating the community (society), is necessary for creating a civil society and ensuring its sustainable development (SERAGELDIN, GROOTAERT 1998). Understood in terms of a social structure, social capital comprises the mutual obligations and expectations of the members of a group, which are determined by their social roles, 
access to information, existing norms and effective social sanctions, power relations, structure enabling the accomplishment of specific goals and structure reducing transaction costs (COLEMAN 1990). Social well-being that depends on the available stock of social capital consists of material living conditions and socio-political factors (the freedom to express political views, the degree of the democratization of life, and the social status of individuals). It is also related to the system of values resulting from the political choices made by the public (STANIEK 2005).

Among researchers studying social capital in Poland are sociologists SZTOMPKA (SZTOMPKA 2007) and CZAPIŃSKI. The latter, who made it a household word, carries out regular surveys called "Social Diagnosis" that reveal an exceptionally low stock of social capital in Poland, with a glaringly insufficient level of public trust accompanied by reluctance towards collective action. The picture arising from international studies is similar - the EU's score for trust in other people is on average 2-3 times higher than Poland's, and the Scandinavian countries' score is approx. 5 times higher (THE EUROPEAN SOCIAL SURVEY). The negative consequences of a lack of social capital have been studied with respect to economic development (KOWALEWSKI et al. 2013) and the quality of services provided by public administration (WNUK-LIPIŃSKI 2014). Studies of spatial variations in social capital show its stocks to be different between regions (WĘZIAK-BIAŁOWOLSKA 2011).

Studies investigating the causes of problems faced in building a civil society resulted in the development of concepts attributing them to the passive and demanding attitudes of homo sovieticus (KURCZEWSKA, STASZYŃSKA, BOJAR 1993; SZTOMPKA 2000), events dating back to the partition times (BARTKOWSKI 2003), patronage-based relationships between third-sector organisations and their institutional and political setting (GLIŃSKI 2004), and the cartelisation of the NGO sector (Graff 2010). Regardless of which of these are true, citizens still rarely take action in the public sphere, unless on spur of the moment or to stage a vocal protest.

One of the main areas where these behaviors can be well observed is the land use planning process. There are many international studies investigating the effect of social capital on local communities' propensity to participate in this process (WOOLCOCK 2004). As a result of studies recommending the use of measures increasing citizens' interest in municipal land use planning, special educational programs have been developed (MANDARANO 2015).

\section{Land use planning - procedures and residents' participation}

Along with the political transition in Poland, the public, civic factor was introduced (in the legal sense) into many spheres of life. Special statutory provisions were enacted to regulate public participation, the importance of which was appreciated by finding a place for it in the Constitution of the Republic of Poland. The range of citizens' constitutional rights includes the right to receive information about the activities of organs of public authority (art. 61) and about the quality of the environment (art. 74), as well as the right to vote in elections and referenda (art. 62 and art. 63). Every citizen is allowed to submit petitions, proposals and complaints in the public interest, in their own interest and in the interest of another person, with their consent, to organs of public authority and organizations and social institutions with respect to the delivery of tasks within public administration.

As for public participation in land use planning, the land use act of 7 July 1994 (Dz. U. 1994 no. 89 item 415) provided local communities with instruments allowing them wide access to this process. The fundamental land use planning provisions of the act offered protection based on the statement that, within the boundaries of the law and the principles of community life, everyone has the right to use property they have a legal title to and to protect their legal interest in using land possessed by other entities. The act also gave each citizen the right to call for the preparation of a local master plan or for making changes to it. Furthermore, it made the executive authorities responsible for individually informing property owners or property holders whose legal interest might be affected by the provisions of the plan, property owners who might be charged a planning fee, persons whose proposals for the draft plan were rejected (stating the reason for the rejection) about the next steps (the date of public display of planning documents, the date of the session at which the council will review complaints and objections dismissed by the executive authority, and the date when a resolution rejecting protests and objections will be passed). Public announcements about planning documents being put on display were made mandatory. Although informing property holders that can be affected by a master plan on an individual basis is costly, it keeps them abreast of the most recent planning developments, thus giving them time to react. 


\section{S sciendo}

The Act of 1994 was replaced by a new land use and planning act of 27 March 2003 (Dz.U. 2016 o. 0 item 778), which considerably reduced the number of measures imposed on executive authorities to ensure citizens' participation in land use planning activities. Personal notices for potentially interested persons were removed; likewise, complaints and objections were replaced by proposals and comments. The act defined sustainable development and spatial order, making them crucial factors in land use and planning. It became a requirement to hold public meetings on planning matters with the participation of the planner, but announcements about such events could be general and published in the local media and on the municipality's BiP website.

Public participation was made part of spatial planning in view of counteracting possible deficits in democracy (ZACHARIASZ, NELICKI 2008). To accomplish this goal, local authorities were allowed to enter into dialogue with the residents also using instruments other than those made mandatory, or to make the existing solutions friendlier to the residents, for instance by keeping planning proposals on display for a longer period (PAWŁOWSKI 2015). In fact, however, although public participation is a mandatory element of the land use planning process, it does not require the executive authorities to accept residents' proposals and comments and is based on vague law, so its position is formal rather than real (BUCZEK 2006) and it is rarely practiced (GONDA-SOROCZYŃSKA 2006).

At the legislative level, public participation was taken into account in the drawing up of the Architectural and Building Code. Article 17 of the Code defines land use planning as a participatory and public process and requires public authorities to state reasons for their decisions, unless the Code states otherwise. Chapter II, Section I of the Code is even more specific on this matter. It is worth taking note of the fact that the organisation of public discussions was specifically regulated by the legislature, which stated that the dates, venues and manner of facilitation of such meetings must enable the participation of a possibly large group of people, including individuals with disabilities. In particular, public discussions must be held after regular working hours and in venues located in areas relevant to the documents to be discussed. Public authorities were also given a clear indication that they could use other means of communication with citizens, particularly meetings, debates, workshops, study walks, surveys, interviews and contacts with community representatives (Kodeks architektoniczno-budowlany, draft document of 30 Sept. 2016).

\section{Citizens' participation in land use planning - findings of studies to date}

The spatial planning and management process determines the possible uses of land and thus influences its value. This is a sphere where the interests of different parties compete, private against public, and private against private. The rules of spatial order and sustainable development intended as the pillars of planning processes are frequently ignored in practice (ZASTAWNIK 2013). The purpose of public participation is to reconcile diverse expectations and interests of the parties, but its effectiveness depends largely on the willingness of property owners and decision-makers to seek cooperation and compromise. Studies point to the scarcity of social capital in this area, as private interests are obviously preferred over the common good (KOPEĆ 2009). This is a clear symbol of the difficulties faced in the creation of a civil society.

There are at least three categories of studies dealing with citizens' participation in land planning and management: 1) works describing the general rules of participation and frequently drawing comparisons with rules adopted by other legal systems; 2 ) analyses of planning processes carried out in some selected area (a municipality, a group of municipalities); 3 ) studies investigating conflicts over land use. Representatives of the first category of studies are authors of comments on the land use act, such as NiEWIADOMSKI (2003), KWAŚNIAK (2009), OLEJNICZAK-SZAŁOWSKA (1995), SIEMIŃSKI (2000, 2007), BUCZEK (2006), GAWRYSZEWSKA (2010) AND WÓJCICKI (2013). The second line of research is represented by ZASTAWNIK (2013), OCIEPA-KUBICKA (2015) and KIKOSICKA (2014). Among the authors of the third category of studies are KAMIŃSKI (2002), PAWŁOWSKA (2008), MiCHAŁOWSKA (2008), ŚLESZYŃSKI and SOLON (2010) and BEDNAREK-SZCZEPAŃSKA (2016).

To set this study in a wider context, let us present an overview of the findings of some selected studies. Public participation studies are frequently based on questionnaire surveys. OCIEPA-KUBICKA (OCIEPA-KUBICKA 2015) used the tool to analyze citizens' awareness and willingness to participate in spatial planning. Her study showed their interest in this process to be limited to verbal declarations, which did not translate into their actual participation in procedures designed to give them a real role. OCIEPA-KUBICKA contributed this passiveness to the incomprehension of planning laws and procedures, problems with understanding master plans, residents' unawareness that they can 
influence land use planning, insufficient information about the commencement of work on local planning documents and of public discussions, and residents' disinterest in possible changes to land use. KIKOSICKA (KIKOSICKA 2014) and DAMURSKI (DAMURSKI 2011) reached similar conclusions. OCIEPA-KUBICKA also points to the local communities' deficit of knowledge and concludes that the situation can be to the advantage of municipalities that can easily carry on with their land use plans.

This situation prevents public participation in land use management from fulfilling its main function, which is to prevent conflicts over land use. Having analyzed 89 such conflicts noted in the voivodeship of Lodz between 2001 and 2005, MicHA£OWSKA found that most of them had been provoked by developing large industrial projects such as wind farms, industrial facilities and dump sites, as well the routes of new roads. She concluded that the underlying cause of the conflicts were land use decisions being made without local residents. According to MiCHAŁOWSKA, the process of conflict escalation can be divided into four stages: an investor submits a project proposal and negotiates its conditions with local authorities, planning procedures necessary to proceed with the project are implemented, the local community is informed about the project, residents become increasingly aware of project risks and conflict groups emerge. During the first three stages, residents are typically not interested in the upcoming changes and the use of statutory tools by the local authorities (e.g. public announcements) does not change this attitude. It is not until the project starts taking shape that residents spring into action and a full-scale conflict erupts. They start seeking experts who could support their case, inform the media and public authorities, and seek assistance from ecological organizations. MiCHAŁOWSKA argues that one of the factors causing a conflict to escalate is that the parties speak different languages (residents express themselves emotionally and the investor and local authorities use technical and formal language), which prevents the creation of a common platform of understanding. The investor's typical response to a conflict is denial and continued work on the project; sometimes financial compensation is offered. In her study, MiCHAŁOWSKA highlights the local authorities' support for the investor. Although administrative law assigns local authorities the role of an impartial arbitrator, in the analyzed cases, they evidently sided with the investor. Local communities were not viewed as an equal partner to decision making, but rather as a passive recipient.

\section{Results of the author's own research}

The author decided that the municipality she selected should be analyzed in more detail, because situations differ from case to case and it is not possible to draw more profound conclusions unless the sequence of developments is reviewed. The analysis is based on the selected municipality's planning documents, numbers of residents attending public meetings, the records of discussions held between local authorities and residents, and documents made available by the association Zrównoważony Rozwój Konstantynowa Łódzkiego (Sustainable Development of Konstantynów Łódzki).

The first part of the analysis deals with residents' participation in the land planning processes in the town of K. $€$. between 2003 and 2015. The second part provides an insight into the background and course of a land-use conflict in Konstantynów Łódzki, and the level of public interest in it. The town and the specific conflict were chosen because the intensity and persistence of the conflict allowed the residents' activity to be studied over a longer period of time, and because a small town (population of around 17,000) bordering on a large urban agglomeration (Eódź) provided an opportunity to observe many typical problems related to land use planning.

The research spanned the years from 2003 to 2015 and involved the examination of 39 procedures involving the preparation and changes to local master plans and 4 procedures aimed to prepare and modify the study of land use conditions and directions in Konstantynów Łódzki. The level of residents' involvement was found not to differ from that reported by other authors. Only 4-6 persons attended public meetings to discuss the study (a critical planning document in the municipality) and the projected changes. The highest number of residents that had ever turned up to discuss a master plan proposal was 24 (in 2008). This unusual turnout was caused by a severe conflict over its content. Other meetings devoted to master plan proposals attracted fewer participants (8 and 7 persons, respectively). In 27 cases, persons representing private entities that could be affected by new solutions did not turn up at all. The highest number of submitted comments (on a change to the study) was 13, and, in 17 cases, no comments were made. The highest numbers of comments on a single procedure were 12 (changes to the study) and 6 (changes to the master plan); in 20 cases, comments were not 


\section{\$ sciendo}

submitted. This meagre interest was to unfold into a major conflict over land use.

\section{Background:}

In December 2015, an investor, i.e. MLP Group, announced preparations for a massive project aimed to develop a logistic center in Konstantynów Łódzki. The project involved the construction of 90000 sq. $\mathrm{m}$ of storage and production space on a 17 ha plot. Because the project site was described in general terms and the part of the town bordering on the city of Lodz was occupied by a special economic zone, residents believed that the new center would be constructed in the zone. However, information started to circulate that the actual site of the project was very close to "Srebrna Ostoja", a housing estate of detached houses (the distance between the plots was around $60 \mathrm{~m}$ ). Somewhat farther away, there was the housing estate of "Srebrna Polana" that consisted of family houses completed and conveyed to their owners between 2013 and 2014. The parties to the emerging conflict were local authorities supporting the project and the buyers of houses and local residents who objected to it. The investor's role consisted in the preparation of documents necessary to apply for an environmental assessment decision. The housing estate developer was also involved in the conflict, but, to the disappointment of his clients, did not object to the project. The unfolding conflict drew the attention of the media, including TVP. In May 2016, the active members of the group of dissatisfied residents formed the association "Zrównoważony Rozwój Konstantynowa Łódzkiego", which increased its membership from 10 founding members to 34 members. During the period for submitting comments on the environmental assessment decision, many residents were active, including persons other than the association's members. In May 2016, the mayor of Konstantynów Łódzki made the environmental assessment decision, thus allowing the investor to proceed with the project. Thirty-two persons decided to appeal from the decision to the Local Government Appellate Court, which rescinded it in November 2016 and sent it back for re-examination. In the meantime, the investor pulled back from the project. All these developments were accompanied by other activities in early June, the association submitted, to the mayor, a petition against the siting of an industrial facility near the housing estate, which was signed by 33 persons. At the end of August, the mayor responded that, because property owners were inactive and failed to submit pertinent motions, the mayor felt legitimized to proceed as he deemed right.

A new investor turned up, with a similar project for the controversial location. In preparation for the environmental decision, the mayor set up a meeting for local residents, representatives of the local authority and the investor (87 persons in total). The mayor stated explicitly that the project would have all the support it may need. The environmental decision was made in January 2017 without the assessment of the project's environmental impacts, even though such assessment was recommended by the Regional Directorate for Environmental Protection and the State Sanitary Inspection. Only 9 persons submitted their opinions before the decision was issued. Seven persons decided to file a lawsuit at the Local Government Appellate Court.

The nature of this local conflict corresponds to what Michałowska reported, particularly with respect to the significance of local authorities as an active disputant siding with the investor. The sequence of events leading to a full-blown conflict also seems to resemble that described by Michałowska. Having noted these similarities, the author would like to explore, in more depth, the activity of local residents.

In the master plan of 2009, the disputed project site and the adjacent plots were assigned a residential function. Public meetings organized to discuss its initial version were attended by 3 residents and 2 comments were made on its content. In 2014, the owner of the future project site (a board member of the company developing the "Sterna Ostoja" estate) applied for converting the site's use into industrial (in fact, the site was allowed to have more than one use; their range included depots and warehouses, industrial facilities, a photovoltaic power station, and commercial facilities). The residents' obvious lack of interest in the land use planning process is illustrated by the fact that only 1 resident turned up to discuss the proposed changes and only 2 comments were submitted. Such a confrontational change to the master plan did not arouse the interest of the owners of the adjacent houses; those who were likely to be the most affected by it were not yet known- the first potential buyers of the nearby houses did not show up until the beginning of 2015. They did not expect a logistic centre close to their properties because the first version of the information materials supplied by the developer provided the number of the master plan and described the function of the adjacent area as residential. It is probable that it was simply the lack of information that made the conflict so 
fierce.

The owners of houses built in the earlier period reviewed the master plan at the time of buying their properties, but then lost interest in the municipalities' planning activities. Some claimed (probably referring to the previous act) that a master plan could not be changed unless all property owners were notified in writing about an intended change, so the situation was under control.

According to OCIEPA-KUBICKA, insufficient knowledge and information about spatial planning activities contribute to the residents' non-participation in the making of land use decisions. It is probable that the situation in Konstantynów Łódzki may have had the same source. Announcements that plan proposals would be put on view and that public meetings to discuss them would be held were published in the press, displayed on the municipality's noticeboard and posted to the BiP website. Meetings always started at 12 p.m., the records of discussions were not published and local authorities did not take any measures to get the residents more interested in the planning process.

In the author's opinion, there is one more question that needs consideration. The above conflict over the construction of the logistic center has two important aspects: the residents' efforts to safeguard their interests and the emergence of a civil society. According to the existing studies, conflicts lead to the development of strong ties between the members of groups representing the common cause and encourage public participation (SKRZYPIEC 2010; BEDNAREK-SZCZEPAŃSKA 2016). The case of Konstantynów Łódzki is quite surprising because of its residents' low activity in the "second round" of skirmishes with the investor. It might be expected that because the "at-risk" residents became acquainted with one another while working together and were successful following the first round, the foundations of a civil society should have emerged, as well as stronger involvement in the next stages of the process. However, this was not so. It is, nevertheless, possible that other ties (e.g. related to the formation of the so-called primary group) were established. If yes, the local authorities' opinion that only the pettifoggers stayed on the battlefield would not be true. Is it probable that, what we are dealing with, in this particular case, is the development of ties and confidence (representing social capital) in the protest leaders. It is unquestionable that a coherent primary group came into being (ŻUKOWSKI 2009) and informally assumed responsibility for acting on behalf of all other residents.

\section{Conclusions}

More than 20 years after the spatial planning law was changed in Poland, master plans and planning permissions have been assimilated by citizens. Still, in the author's opinion, citizens' non-participation in land use planning is of dramatic proportions. A very relevant question is why people do not become active until a clear-cut conflict of interests becomes noticeable, why they refrain from activity as long as processes follow their regular course. An outcome of this non-participation are numerous local conflicts that are frequently fueled by the NIMBY attitude. Parties put forward conflicting interests and expectations, but no mediator is available to help disentangle them and propose a compromise solution. The situation is aggravated by the lack of tradition to cooperate, of forging a compromise, and of collective responsibility for local matters.

The law, as it stands today, does not require municipalities to personally notify the residents about the commencement of a planning procedure that can affect their properties, but the possibility of preventing conflicts, some of which may escalate into severe ones, seems to outweigh the cost of having a municipal worker deliver personal notices to the interested persons. In some countries, land use information is distributed to all residents in the municipality on an annual basis to update them on the ongoing land use planning processes. The Architectural and Building Code's provision on participation seems to be a step in the right direction, but detailed solutions will not be known until secondary legislation is adopted.

The lack of social capital in Poland, confidence deficits, and the difficulties faced in building social capital are discussed by many studies. As it seems, the most severe symptom of these problems is that residents are considered to be on the receiving end of municipal decisions. It contrasts with the fact that, for basic social relations to exist, ties based on trust and a sense of empowerment are necessary. A municipality is a community of residents - local authorities should not erect walls between themselves and residents, nor should they consistently stick to their judgements regardless of the residents' opinions and favor entities of their choice, as this attitude erodes residents' trust in public institutions. It appears that a lack of knowledge and information is as much a reason for residents' 


\section{S sciendo}

non-participation in the land planning process as the way local activities act and behave. The situation when public participation is part of an administrative procedure but is met with a reluctance to give it a real meaning leads to non-participation, which is very convenient for the authorities. The situation has its downside, however, i.e. when residents do not feel that they share in the responsibility for their community, conflicts arise and it becomes impossible to create social capital necessary to form local ties.

Because the analyzed municipality has the long-standing problem of residents' low participation in land use planning processes, the author would think it advisable for its authorities to deploy nonmandatory instruments to attract local residents to planning processes. Educational activities have the potential to make the law in force more comprehensible and to show the residents possible ways of influencing the outcomes of processes. In time, the approach may prevent the emergence of possible neighborly conflicts over the use of land and give the residents a sense of empowerment and collective responsibility for land in their municipality. The problem of non-participation has already been identified in other countries that tackled it by developing dedicated educational programs.

\section{References:}

BARTKOWSKI, J., 2003, Tradycja i polityka: wpływ tradycji kulturowych polskich regionów na wspótczesne zachowania spoteczne i polityczne (Tradition and Policy: the Effect of Cultural Tradition of the Polish Regions on Contemporary Social and Political Conditions), ŻAK.

BEDNAREK-SZCZEPAŃSKA, M., 2016, Wptyw konfliktu typu NIMBY na wiejska społeczność lokalna (The Impact of Nimby Conflict on a Rural Local Community), Studia Obszarów Wiejskich 41, 43-61.

BUCZEK G., 2006, O potrzebie zwiększenia partycypacji społecznej w planowaniu miejscowym (The Need for Increasing Social Participation in Planning), Urbanista Nr 11(47)..

CAldeIRA T., \& Holston J., 2015, Participatory Urban Planning in Brazil. Urban Studies, 52(11), 20012017.

Coleman, J. S., 1990, Foundation of Social Theory, Cambridge, Masachusetts.

CZAPIŃSKI, J., 2013, Diagnoza Społeczna 2013 Warunki i Jakość Życia Polaków (Social Diagnostics 2013 Conditions and Quality of Polish Life), Cały Raport (Entire Report) (PL). Contemporary Economics, 7(3.1).

DAMURSKI, Ł., 2011, Wyniki ankiety internetowej „Gra o przestrzeń: urbaniści versus mieszkańcy” (Results of the Internet Survey "Game of Space: Urban Planners Versus Developers"), KGP, SEQ-Kwartalnik Gospodarka Przestrzenna (Spatial Economics Quarterly), Suplement: Raporty z badań, (1),

EDWARDS, M., 2009, Civil Society, Polity.

GAWRYSZEWSKA B.J., 2010, Uczestnictwo spoteczne w gospodarowaniu przestrzenia gminy. Kultura przestrzeni gminy (Social Participation in the Management of Commune Space. Culture of Commune Space), Wydawnictwo SGGW, Warszawa.

GLIŃSKI, P., 2004, Bariery samoorganizacji obywatelskiej (Barriers to Self-organization of Citizenship) in: H. Domański, A. Ostrowska and A. Rychard (ed.), Niepokoje polskie, Warszawa: Wydawnictwo IFiS PAN.

GONDA-SOROCZYNSKA, E., 2008, Udział spoteczności lokalnej w rozwoju ziem górskich (Participation of Local Communities in the Development of Mountain Lands). Infrastruktura i Ekologia Terenów Wiejskich, (08).

GRAFF, A., 2010, Urzędasy, bez serc, bez ducha (Clerks Without Hearts and Souls), Gazeta Wyborcza, 6, 2010.

Hanssen, G. S., FAlleth, E. I., 2014, Market-Oriented Urban Planning-Constraining Citizen Participation. Local Government Studies, 40(3), 403-428.

KALISIAK-MĘDELSKA, M., 2015, Partycypacja spoteczna na poziomie lokalnym jako wymiar decentralizacji administracji publicznej $w$ Polsce (Social Participation at the Local Level as a Measure of the Decentralization of Public Administration in Poland). Wydawnictwo Uniwersytetu Łódzkiego.

KAMIŃSKI, Z., 2002, Pojęcie konfliktu w planowaniu przestrzennym (Concept of Conflict in Spatial Planning), Zeszyty Naukowe. Architektura/Politechnika Śląska, (40), 3-132.

KIKOSICKA, K., 2014, Partycypacja społeczności lokalnej w planowaniu przestrzennym (przykład gminy Dąbrowice) (Participation of Local Communities in Spatial Planning (Case Study of Dabrowice Commune)), Acta Universitatis Lodziensis, Folia Geographica Socio-Oeconomica No. 16, 97-113.

KODEKS ARCHITEKTONICZNO-BUDOWLANY, PROJEKT Z 30.09.2016, Rządowe Centrum Legislacji, UD 135. (Architecture-Building Code). 
KOPEĆ A., 2009, Udział społeczny w planowaniu przestrzennym - uwarunkowania prawne a praktyka planistyczna (Social Participation in Spatial Planning - Legal Conditions and Planning Practice), [in:] Czynniki społeczne $\mathrm{w}$ gospodarce przestrzennej i planowaniu przestrzennym (Space-SocietyEconomy), 9, Łódź, pp. 35-42,.

KowAlewSKI, A., MoRDASEwicz, J., OsiATYŃSKI, J., RegUlSKI, J., ŚLESZYŃSKI, P., 2013, Raport o ekonomicznych stratach $i$ społecznych kosztach niekontrolowanej urbanizacji w Polsce (Report on Economic Losses and Social Costs of Uncontrolled Urbanization in Poland), PAN IGiPZ, Warszawa.

KURCZEWSKA, J., STASZYŃSKA, K., OJAR, H., 1993, Blokady społeczeństwa obywatelskiego: czyli stabe społeczeństwo obywatelskie i stabe państwo (Blockades of a Civil Society: Weak Civil Society and Weak State), in: Społeczeństwo w transformacji. Ekspertyzy i studia (Society in Transformation. Expert Opinions and Studies) (ed.:) Rychard A., Fedorowicz M., Warszawa,.

KWAŚNIAK, P., 2009, Plan miejscowy w systemie zagospodarowania przestrzennego (Master Plan in the Spatial Planning System), LexisNexis.

Mandarano, L., 2015, Civic Engagement Capacity Building: An Assessment of the Citizen Planning Academy Model of Public Outreach and Education. Journal of Planning Education and Research, 35(2), 174-187.

MiCHAŁOWSKA, E., 2008, Syndrom NIM BY jako przykład samoorganizacji społecznej na poziomie lokalnym (NIMBY Syndrome as an Example of Social Self-Organisation on Local Level). Studia Regionalne i Lokalne (Regional and Local Studies), 9(31), 60-80.

NARED J., Visković N. R., CREMER-SChUlTE D., BrOzZI R., GARCiA F. C., 2015, Achieving Sustainable Spatial Development in the Alps Through Participatory Planning, Acta geographica Slovenica, 55(2).

NiEWIADOMSKI, Z., 2006, Planowanie przestrzenne: zarys systemu (Spatial Planning: Outline of the System), Wydawnictwo Prawnicze" LexisNexis".

OCIEPA-KubICKA, A., 2015, Udział społeczności w procedurze planowania przestrzennego (Social Participation in the Spatial Planning Procedure), Inżynieria i Ochrona Środowiska (Environmental Engineering and Protection), 18,

OLEJNICZAK - SZAŁOWSKA E., 1995, Uspotecznienie procesu planowania przestrzennego: zagadnienia administracyjno-prawne (Socialization of the Spatial Planning Process: Administrative-Legal Issues), Studia Prawno-Ekonomiczne (Legal-Economic Studies), Vol. 52.

PaCione M., 2014, The Power of Public Participation in Local Planning in Scotland: the Case of Conflict over Residential Development in the Metropolitan Green Belt, GeoJournal, 79(1), 31-57.

PAWŁOWSKA, K., 2008, Przeciwdziałanie konfliktom wokót ochrony i ksztattowania krajobrazu: partycypacja spoteczna, debata publiczna, negocjacje (Conflict Prevention Around the Protection and Development of Landscape: Social Participation, Public Debate, Negotiations), Wydawnictwo Politechniki Krakowskiej (Kraków University of Technology Publishing House).

PAWŁOWSKI, S., 2015, Konsultacje obligatoryjne i fakultatywne w ustawie o planowaniu i zagospodarowaniu przestrzennym a zakres uspołecznienia procesów planowania przestrzennego (Obligatory and Optional Consultations in Spatial Planning and the Scope of Socialisation of Spatial Planning Processes), Ruch Prawniczy, Ekonomiczny i Socjologiczny (Legal, Economic, Sociological Movement), 77(1), 203-217.

SERAGeldin, I., GROOTAeRT, C., 1998, Defining Social Capital: an Integrating View, INJVVdO1JA3O, 203.

SIEMIŃSKI W., 2000, Partycypacja społeczna w procesie zarzadzania miastami w Polsce (Social Participation in Urban Management in Poland)., Człowiek i Środowisko (People and the Environment), No. 1.

SIEMIŃSKI, W., 2007, Cele i zasady partycypacji spotecznej w planowaniu przestrzennym-przegląd literatury (Aims and Rules of Social Participation in Planning Processes - Review of Literature), Człowiek i Środowisko (People and the Environment), 31(1-2), 37-59.

SKRZYPIEC, R., 2010, Konflikt lokalny motorem partycypacji spotecznej $i$ skutkiem zmiany-analiza wybranych przypadków: Oświęcim, Bierun, Las i Kobiór (Local Conflict as a Trigger of Social Participation and Consequence of Change - Analysis of Selected cases: Oświęcim, Bieruń, Las and Kobiór), Partycypacja społeczna i aktywizacja w rozwiązywaniu problemów społeczności lokalnej (Social Participation and Activation in Solving Problems of the Local Community), 126.

SowA K. Z., 2012, Szkice o sferze publicznej i polskim społeczeństwie obywatelskim (Sketches on the Public Sphere and the Polish Civil Society), Wydawnictwo Uniwersytetu Jagiellońskiego (Jagiellonian University Press), Kraków.

SZACKI, J., 1997, Ani ksią̇ę, ani kupiec: obywatel. Idea spoteczeństwa obywatelskiego w myśli wspótczesnej, wybór tekstów i wstęp Jerzy Szacki (Neither Prince nor Merchant: Citizen. Idea of a Civil Society in Current Thought) Społeczny Instytut Wydawniczy Znak, Kraków-Warszawa. 
WNUK-LIPIŃSKI, E., 2014, Długie pożegnanie. Homo sovieticus dzisiaj (Long farewell. Homo sovieticus Today)., Tygodnik Powszechny (Universal Weekly)

SzTOMPKA, P., 2000, Trauma kulturowa. Druga strona zmiany społecznej (Cultural Trauma. The Second Side of Social Change).Przegląd Socjologiczny, 49(1),

SzTOMPKA, P., 2007, Zaufanie: fundament społeczeństwa (Trust.: a Social Foundation), Wydawnictwo Znak,

ŚLESZYŃSKI, P., SOLON, J. (RED.), 2010, Prace planistyczne a konflikty przestrzenne w gminach (Planning Processes and Conflicts in Municipalities). Komitet Przestrzennego Zagospodarowania Kraju,

THEISS, M., 2010, System pozornie otwarty. O instytucjonalnych uwarunkowaniach lokalnej partycypacji politycznej w Polsce (A Seemingly Open System. On the Institutional Conditioning of Local Political Participation in Poland), Partycypacja społeczna i aktywizacja w rozwiązywaniu problemów społeczności lokalnych (Social Participation in activization in Solving the Problems of Local Communities), 61-80, in: Schinler, J., Skrzypiec, R., and Lewenstein, B.(eds.)

WĘZIAK-BIAŁOWOLSKA, D., 2011, Ocena kapitału ludzkiego oraz jego zróżnicowanie demograficzne, społeczne $i$ ekonomiczne w Polsce $i$ województwie podkarpackim-analiza porównawcza (An Assessment of Human Capital and its Demographic, Social ad Economic Differentiation in Poland in Podkarpackie Province Comparative ), Studia Regionalne i Lokalne (Regional and Local Studies) 2 (44), 41-57,

Woolcock Michael. 2004. Why and How Planners Should Take Social Capital Seriously. Journal of the American Planning Association 70 (2): 183-89.

WójCICKI, M., 2013, Pojęcie, istota i formy partycypacji społecznej w procesie planowania przestrzennego (Social Participation in Planninig)., Rozwój Regionalny i Polityka Regionalna, 169,

ZACHARIASZ I., NELICKI A., 2008, Skuteczność planowania przestrzennego na poziomie lokalnym a partycypacja spoteczna (Effectiveness of Spatial Planning at the Local Level and Social Participation), Zarządzanie Publiczne 2 (4), 97-108.

ZASTAWNIK, A., 2013, Kształtowanie przestrzeni z udziatem spoteczności lokalnych w procesie planowania przestrzennego na wybranych przyktadach $z$ gmin małopolskich (Shaping Space with Participation of Local Communities in the Spatial Planning Process), praca doktorska (PhD thesis), Biblioteka Cyfrowa Politechniki Krakowskiej.

ŻUKOWSKI T., 2009, Samoidentyfikacje Polaków i ich wptyw na aktywność społeczna (Self-identifications of Poles and their Impact on Social activity, in: K. Zagórski (red.), Życie po zmianie (Life after Change), Warunki życia i satysfakcje Polaków (Living Conditions and Satisfaction of Poles) Wydawnictwo Naukowe "Scholar" ("Scholar" Scientific Publishing), Warszawa. 